\title{
Legal Analysis on Local Content Requirements Regulation for Modern Retail Business in Indonesia
}

\author{
Muhammad Iqbal Pratama ${ }^{1 *}$ and Rouli Anita Velentina ${ }^{1}$
}

\author{
${ }^{1}$ Faculty of Law, Universitas Indonesia, Depok, Jawa Barat, Indonesia \\ *Corresponding author. Email: balprat@gmail.com
}

\begin{abstract}
This research paper examined the adjustment of domestic Local Content Requirements rules in Indonesia for the implementation of Modern Retail business in Indonesia and the Local Content Requirements provisions of the WTO. Indonesia showed their self-approval to WTO by ratifying Law Number 7 of 1994 concerning the Ratification of the Agreement Establishing The World Trade Organization on November 2, 1994 (Dirdjosisworo, 2004). However, since 2014, the Government of Indonesia has received protests from WTO member countries such as The European Union, Japan, the United States, Australia and New Zealand in relation to the Local Content Requirement policy in the form of fulfilling $80 \%$ (eighty percent) of domestic products that must be sold on the modern retail market on Ministry of Trade Regulation 53/2012, 68/2012, and 70/2013 which was replaced by Regulation 56/2014. These provisions are contrary to the TRIMs Agreement, principled by Article III GATT on National Treatment and Article XI GATT on General Elimination of Quantitative Restrictions, which is an annex to the WTO Establishment Agreement that has been ratified by Indonesia. Comparison between the regulations of Indonesia's local content requirements and WTO provisions will be done by looking at the adjustments between regulations and the application of WTO exceptions. Based on rules of Local Content Requirements, the Modern Retail has violated TRIMs Agreement with no applicable exceptions on the provisions.
\end{abstract}

Keywords: Indonesia, Domestic Goods, Local Content Requirements, TRIMs Agreement, GATT, World Trade Organization

\section{INTRODUCTION}

Indonesia has issued regulations for modern retail businesses to limit the sale of its product in Ministry of Trade Regulations 58/2012 regarding Management of Franchise (Penyelenggaraan Waralaba), 68/2012 regarding Franchising for Modern Retail (Waralaba untuk Jenis Usaha Toko Modern, and 70/2013 which was replaced by 56/2014 regarding the Guidlines for the Arrangement and Development of Traditional Markets, Shooping Centers, and Modern Retail Stores (Pedoman, Penataan, dan Pembinaan Pasar Tradisional, Pusat Perbelanjaan, dan Toko Modern).. The limit of products being sale is carried out by limiting $80 \%$ (eighty percent) of local product to be displayed and sold. If a modern retailer sells ten similar items with different brands, at least eight items must be local products. Those regulations were made to protect domestic production as well as MSMEs. However, the noble goals have been challenged by Indonesian trading partners in the International World. World Trade Organization Member countries such as the USA, European Union, Australia, and Japan had filed their concern to the TRIMs Commitee since 2014 due to the regulations implemented by Indonesia were considered a distruption to their trade interests.
Modern retail store was first present in Indonesia when the Sarinah department store was established in 1962 and developed very rapidly in the 1990s when the Sogo department store entered the Indonesian market (Martinus, 2011). Modern retail stores can be distinguished from traditional stores by its filxed price, good maintenance, high technology usage, and other features (Hikmawati \& Nuryakin, 2017). However, It was not until 2007 when the Presidential Decree 112/2007 was entried into forces, being the first regulation regarding modern retail business. On Article 14 of this decree, it was mandated to the Minister of Trade to issue the regulation 53/2008 regarding the Guidlines for the Arrangement and Development of Traditional Markets, Shooping Centers, and Modern Retail Stores (Peraturan Menteri Perdagangan No. 53/2008 tentang Pedoman, Penataan, dan Pembinaan Pasar Tradisional, Pusat Perbelanjaan, dan Toko Modern) which are replaced by Regulation 70/2013 and 56/2014.

The emergence of regulations requiring the sale of domestically produced goods occured in several stages. First, the existence of Regulation 53/2012. Article 19 of this regulation concerning the implementation of a franchise that requires the use of raw materials, business equipment, and the sale of goods at least $80 \%$ (eighty percent) of goods produced domestically. Second was the emergence of 
Regulation 68/2012). Article 7 of this regulation stated that both franchisor and franchisee for modern retail business must provide domestic production of goods at least $80 \%$ (eighty percent) of the amount and type of goods being sold. Third, Regulation 70/2013 in which some of its articles have been replaced by Regulation 56/2014. It was stated on Article 22 Regulation 56/2014 that replaced Article 22 Regulation 70/2013 that Self-managed modern retail and shopping centres must provide domestic products goods at least $80 \%$ (eighty percent) of the quantity and types of goods traded. This regulation that obliges modern retail to sells domestic production goods is named Tingkat Komponen Dalam Negeri.

Both regulation 53/2012 and 68/2012 regarding franchise are applied to modern retails because on Regulation 56/2014, it was stated that modern retailers must submit document analyzing the socio-economic conditions of the community including partnership plans with MSMEs. This partnership takes form of a pattern of general trading or franchising. Meanwhile, the third regulation of both Regulation 70/2013 and 56/2014 replace its precedent regulation due to it regulates matters that have not been regulated in Regulation 53/2008, one of which is the amount of domestic products in goods in modern retail.

Regulation 53/2012 and 68/2012 provides exception to defer from the regulations concerning the sale of domestically produced goods of at least $80 \%$ in modern retail by Ministerial licences after considering the recommendations of the assessment team. However, it was not stated clearly on who and what qualifications are needed to be part of the assessment team. Next, regulation 56/2014 also provides exception differs from regulations previously mentioned. On this regulation, the Trade Minister grants permission to modern retail stores in form of stand alone brand and/or specialty stores if terms of goods they selling are either: First, Requires uniformity of production and comes from a single global marketing network (global supply chain) - e.g. Otomotive products such as MercedesBenz, Toyota, etc; Then, it owns a brand or a well-known brand in the world (premium product) and yet to have a production base in Indonesia-e.g. Branded bags or shoes such as Louis Vuitton, Tory Burch, Tumi, etc; and Finally, originating from a particular country to meet the demands of its citizens living in Indonesia-e.g. foods on supermarket specifically builds for foreigners.

Those regulations implemented in Indonesia are controversial due to differences in the regulations and states that can override the Local Content Requirements that apply in Indonesia with the regulations of WTO.

The long history of the WTO can be traced to the existence of the GATT in 1947 as a pioneer of International trade (Adolf, Hukum Perdagangan Internasional, 2006). It aims to support world trade that can improve the welfare of its member countries (Kartadjoemena, 1996). In order to achive this goal, they held rounds consistently in different places and years (Das, 2007). In 1994, the Uruguay Round resulted in a Marrakesh Agreement that consists of the establishment of the WTO (Syahmin, 2007). The WTO has a main function as a forum for its member countries to conduct trade negotiations and administrative activities on all the results of negotiations and regulations on International trade. In carrying out these functions, the WTO has the basic principles they adhere to make free trade compiled in accordance to the norms and principles of GATT (Sood, 2011). Among those are the NonDiscrimination principle consisting of Most-Favored Nation principle and National Treatment principle and Elimination of Quantitative Restrictions principle. Both principles that are written underlined will soon become an important and inseparable part of the TRIMs Agreement, as the agreement is based on these two principles.

Non-Discrimination principle is the foremost principle of the WTO in order to carry out its function, consisting of Most-Favored Nation principle and National Treatment principle. Adolf \& Chandrawulan (1994) stated that according to Article I of the GATT, Most-Favored Nation is a principle in which every member countries are bounded to give other member country the same exact policy and implementation for exports, imports, and any other tarriffs. Once these policy and implementation occurs for one country, it must also be implemented immediately and unconditionally for all products from/to all member countries. Hence, the non-discrimination principle that forbid a member country to give preferential treatment to other member country only for its likes.

On the other hand, National Treatment principle is a principle that existed on Article III GATT. This principle prohibits discrimination in the treatment of foreign goods and domestic goods (Jackson, 1969). This prohibition is defined as when an imported item has entered the domestic market of a member by passing the customs area and paying import duty, the imported goods must be treated no worse than domestic products. This principle applies widely and includes all kinds of taxes and other levies, laws and regulations, regulations and legal requirements that affect the sale, purchase, transportation of distribution, or the use of products in the domestic market (Adolf, 2006). However, National Treatment only applies if the product has entered the market. Therefore, the collection of customs duties on imports is not categorized as a National Treatment violation, even if local products are not subject to the same tax fees (World Trade Organization, 2015).

Other than Non-Discrimination principle, the GATT was also based on the Elimination of Quantitative Restrictions principle that was on Article XI of GATT. This principle is the principle that requires the elimination of quantitative "barriers" other than tariffs or import duties in international trade (Sood, 2011). What is categorized as a "barrier" in this principle is quota, restrictions on imports or exports, and other actions that have a significant and important impact on trade (van Houtte, 1995).

In the wake of Marrakesh Agreement which creates WTO Establishment Agreement, there are agreements and associated legal instruments on its annex that are considered 
as an integral parts of the WTO Establishment Agreement. Provided a member country of the WTO sign the establishment agreement, they are also subject to agreements on the annex (Dube, 2012), with no exception to Indonesia that had signed the WTO Establishment Agremeent on Law No. 7/1994 regarding the Ratification of the WTO Establishment Agreemeent. This principle is known as Single Undertaking principle, a principle that based on conduct, conclusion, and entry into force of an agreement on WTO establishment agremeent annex as a result of negotiations must be treated as part of WTO Agreement (Wolfe, 2009). Among all agreements in the annex, there is Trade-Related Investement Measures Agreement (TRIMs Agremeent). Thus, making Indonesia bounded by TRIMs Agrement.

The regulation regarding foreign investment had been aspired since the Havana Charter that established the International Trade Organization (ITO) (Macrory, Appleton, \& Plummer, 2005) that failed as it was deemed to protect developing countries (Adolf, 2004) to the most notable development related to investment which became the cornerstone of the emergence of the TRIMs Agreement was the GATT Panel's decision on the Tokyo Round after the dispute between the USA and Canada regarding Canadian investment policy, the Administration of the Foreign Investment Review Act (FIRA). Under FIRA regulations, foreign investment is only permitted into Canada if the Canadian Government decides that the investment is likely to be of significant benefit to Canada (Dattu, 2000). This regulation requires foreign investors to submit written performance undertakings that require them to meet local content requirements and export performance requirements (Carasco, 1983). This fulfillment is legally binding for investors as soon as the investment is approved (Dattu, 2000). This case was then submitted by the United States to the GATT Panel.

In its decision, the GATT Panel approved the United States' argument which stated that this dispute specifically occurred because of Canada's foreign investment policy to make written undertaking regarding local content requirements that contravene the National Treatment principle stated in Article III Paragraph (4) GATT. The FIRA provisions regarding export performance requirements are also considered to be incompatible with GATT (Dattu, 2000). In addition, the provisions of FIRA also violate Article XI Paragraph (1) GATT regarding quantitative restrictions because of the argument of foreign investors that there is a value-added undertaking to FIRA as Canadian action to limit the import of products contained in undertaking and Article XVI Paragraph (I) due to subsidies not in the form of money (Carasco, 1983). During the Uruguay Round, The FIRA case of USA v Canada leads to an important agenda for the round that resulted in the creation of TRIMs Agreement in WTO Establishment Agreement's annex (Kusumaatmadja, 1996).

The government of a country, not limited to Indonesia, always focuses so that investors invest in their countries to meet domestic demands according to their priorities. The investment is regulated in the presence of performance requirements, local content requirements, local manufacturing, export performance, and technology transfer requirements. The performance requirements of foreign investors made by the Government must be in accordance with the development of the country of origin and consistent with the policy objectives. The government often provides incentives to foreign investors who fulfill these performance requirements in the form of loans and tax deductions. If this incentive is related to trade in goods, then the TRIMs Agreement applies (Vagadia, 2004). This foreign investment has made the Government categorize this as International Trade which should be regulated by the WTO.

Maskus \& Eby, (s.a.) defines TRIMs Agreement as steps in the form of regulations and provisions regarding export performance requirements that require the existence of a minimum export level and domestic content requirements. This definition was used due to the direct link between investment policy and the impact of trade generated. It is stated on TRIMs Agreement Preambule that the purpose of this agreement creation are to promote expansion and progressive liberalization of world trade and to facilitate investment across international frontiers so as to increase the economic growth of all trading partners, particularly developing country Members, while ensuring free competition. The purpose of TRIMs Agremeent does not only include the introduction of free trade expansion, but also to facilitate cross-border investment (United Nations, 2007).

Paragraph 1 Article 2 of the TRIMs Agreement explicitly stated that the core regulation of the TRIMs Agreement is to forbid member country for doing TradeRelated Investment Measure on goods that is incosistent with the provisions of Article III concerning National Treatment principle or Article XI concerning Elimination of Quantitative Restriction principle of GATT 1994 while still maintaining rights and obligations in GATT. Then, on paragraph 2 Article 2 on the same agreement, there are an illustrative list of Trade-Related Investment Measures that are inconsistent with the obligation of National Treatment principle provided for in paragraph 4 of Article III of GATT 1994 and the obligation of general elimination of quantitative restrictions principle provided for in paragraph 1 of Article XI of GATT 1994 is contained in the Annex to this Agreement. This illustrative list includes two types of Trade-Related Investment Measure (will be stated on following paragraph) that are mandatory or can be enforced under domestic law and the measures for which compliance is needed to make a profit. However, the illustrative list posesses weakness that it is not specified on how to deal with problems related to giving National Treatment principle to investors (Bora, 2002).

Based on paragraph 4 Article III of GATT, there are three elements (Usak, 2017) that must be fulfilled to have violated the National Treatment principle, that are: 1. Imports and domestic goods are like products; 2 . There are legal provisions or requirements that affect demand, supply, sales, transportation, distribution, and use; and 3. There is 
less favorable treatment between dmoestic and imported products. It was then written on TRIMs Agreement's first Illustrative List that stated TRIMs that are inconsistent with the obligation of National Treatment principle provided for in paragraph 4 of Article III of GATT 1994 include those which are mandatory or enforceable under domestic law or under administrative rulings, or compliance with which is necessary to obtain an advantage, and which require: (a) the purchase or use by an enterprise of products of domestic origin or from any domestic source, whether specified in terms of particular products, in terms of volume or value of products, or in terms of a proportion of volume or value of its local production; or (b) that an enterprise's purchases or use of imported products be limited to an amount related to the volume or value of local products that it exports. Other than Paragraph 4 Article III of the GATT, Local Content Requirements' root can also be found on Paragraph 5 Article III of the GATT. According to Paragraph IV, contracting parties in the agreement are not allowed to take action or make regulations relating to the mixture, processing, or use of the product in a certain amount or proportion, which requires, implicitly or expressly, that a certain amount or proportion is supplied from domestic sources. Thus, in addition to Article III Paragraph 4, Paragraph 5 also deals with and regulates local content requirements (Shadikhojaev, 2008).

Relating the National Treatment principle in the GATT provisions which was stated on Paragraph (1), (2), and (4) of Article III GATT, it can be found that the Tingkat Komponen Dalam Negeri on modern retail regulations in Indonesia are not in accordance to GATT paragraphs mentioned previously because they constitute a form of legal regulation that affects internal sales and distribution of modern retail import products by requiring the use of local products in carrying out their production activities. This violates the National Treatment Principle due to privileging the use of local products is part of discrimation treatment between foreign goods and domestic goods. Furthermore, violations of the national treatment principle led to the existence of different treatments for similar imported products. Modern retail also possess an obligation to provide domestic production goods in a minimum amount of $80 \%$ (eighty percent) from the amount and type of merchandise being sold. The amount and obligation for the use of domestic products in trading is not in accordance with the provisions of Paragraph (5) Article III GATT.

Meanwhile, on the second Illustrative List that stated TRIMs that are inconsistent with the obligation of General Elimination of Quantitative Restrictions provided for in paragraph 1 of Article XI of GATT 1994 include those which are mandatory or enforceable under domestic law or under administrative rulings, or compliance with which is necessary to obtain an advantage, and which restrict: (a) the importation by an enterprise of products used in or related to its local production, generally or to an amount related to the volume or value of local production that it exports; (b) the importation by an enterprise of products used in or related to its local production by restricting its access to foreign exchange to an amount related to the foreign exchange inflows attributable to the enterprise; or (c) the exportation or sale for export by an enterprise of products, whether specified in terms of particular products, in terms of volume or value of products, or in terms of a proportion of volume or value of its local production (Kusumaatmadja, 1996). Indonesia has also violated the General Elimination of Quantitative Restriction principle in their modern retail regulation by limiting imported products used in the manufacture of merchandise production or selling products in modern retailers to only $20 \%$ (twenty percent).

The provisions in the Illustrative List of the TRIMS Agreement as underlined in the previous wto paragraphs creates the presence of Local Content Requirements, a policy which requires foreign companies or investors to use a certain percentage of raw materials or certain components produced from within the country to be able to intensify their domestic industrial activities (Dewanti, 2012). It is an industrial tool that enable the elaboration of domestic economic activity, in the form of domestic resources joining forces with international technology and expertise in management field. These combination can enhance domestic economic state positively by creating a positive image for future international producers or investor which will compete among each other to invest on a certain country. There are three types of Local Content Requirements (Kalyuzhnova, 2016), with certain dimension of Local Content Requirements which will be explained in the following passage:

First type is the Market-Creating Local Content Requirements, a type arises because of the existence of countries with rich resources with little sectoral diversion and are on a low economic scale to meet domestic needs. The sector suffered losses due to competition from international suppliers of goods, so that local content requirement was needed to ensure that new industries in the new domestic market became more competitive and specialized. This treatment is carried out by giving preferential treatment to domestic supplier through domestic champions. In this situation, countries in exporting special industries and local content requirements will be fulfilled. Such treatment can encourage the state to build new supply networks and new distributions to create new markets. This policy creates new growth and new levels of development as well. In market-creating local content three important things are needed: 1) Policy makers who create a viable economic instrument; 2) Entrepreneurs who see industrial needs that are not met; 3) Exit strategies from local content requirements that drive further innovation and efficiency.

Second, the Sustaining Local Content Requirement that aims that aims to help domestic producers maintaining their existing shares or production. This policy is important when they interact with holders of power and wealth, because it can imply efforts to increase domestic production to meet quality standards. Therefore, investment in this policy does not often create a lot of new short-term growth in the company but intensifies the activation and exit strategy of market-creating policies. In the absence of an exit strategy, 
this policy doubles as a substitute for policies that hinder trades.

And the last one is the Efficiency Local Content Requirement that aims to expand both domestically and internationally economic activity. This policy ensures privileges for companies and products that have a latent comparative advantage. This type does not aim to create a new domestic market or maintain production yet encourages the development and expansion of products to the international market. This is because the aim is to support positive developments in foreign markets through industrial and regional policies that prioritize grouping and networking. This policy is a long-term process with results in a more futuristic future.

Local Content Requirements can also be stated explicitly or implicity. In an explicit form, local content requirements are written numerically or qualitatively in provisions or industrial regulations that specifically regulate the minimum level of domestic goods and / or services. In addition, an explicit form can also be realized with a score card system in which local content requirement becomes a criterion for providing subsidies that will be received by a company, or for products that are targets of Government procurement of goods that are in line with labor policies. The implicit form of local content rfequirements is when there is procurement of goods through an auction whose process is strongly influenced by political considerations, because the statement of the Government official concerned that the use of local content will be highly calculated for auction victory. This is a signal to the bidder that there are provisions regarding the local content implicitly (United Nations, 2014).

According to the writer's opinion, the form of Local Content Requirement in Indonesia modern retail case is the Sustaning Local Content Requirement that was stated explicitly on the regulation. This opinion was supported on the point of consideration of Regulation 68/2012 which stated that in the implementation of modern retail which is always increasing rapidly, it is necessary to increase the MSMEs partnership to be able to increase the supply of domestically produced goods. Thus, it helps domestic producers maintaining their existing shares or production. It was also explicitly stated on all of the regulation that the minimum sale of goods in modern retails are at least $80 \%$ (eighty percent) of goods produced domestically.

In relation to the Illustrative List Annex of the TRIMs Agreement, there are five charcteristics that make a Local Content Requirements policies considered to be include in the framework of the TRIMs Agreement consisting of: (a) Applicable to goods; (b) Is considered an Investment Measures; (c) Is considered a trade-related policies; (d) Implemented in order to gain profit or advantage; (e) Requires the purchase or use of certain domestic products or sources, determined in terms of certain products, volumes, or proportions of the value of local production.

The foremost article of the TRIMs Agreement stated that the agreement is only applicable to investment measures regarding for trade of goods. This condition is fulfilled on the modern retail case due to it explicitly being stated in regulation that modern retail is obliged to provide domestic goods of at least $80 \%$ (eighty percent) of the amount and type of goods being sold.

Although it was not clearly stated on the agreement on the definition of investment measures, the panel of Canada FIT Program (Canada - FIT Program Case, 2012) stated that in order to determine whether a regulation contains investment measures, investment objectives and investment features that allow investment activities by investors are needed. In the context of modern retail, investment objectives are written on regulation's consideration point that wants to improve business certainty and order to intersect with consumers' demand for domestically produced goods while investment features are the exceptions for the sale of goods given by the assesment team or Minister of Trade.

Panel of the FIT Program Case considered on whether a provision contains a trade-related measure is when the local products usage takes precedence over imported products that is impactful on trade (Canada - FIT Program Case, 2012). On regulation $70 / 2013$, it was stated that modern retail must prioritize the supply of domestically produced goods by the MSMEs as long as they fulfill the requirements set by the modern retail itself. This provisions affects the trade as imported product does not have equal chance to be sold at modern retails.

In accordance to gain profit or advantage, the panel agrees that the benefit obtained do not have to be in monetary or physical form (Canada - FIT Program Case, 2012). Compliance with the regulations are also regarded beneficiary in order to avoid sanctions and punishments. While in Indonesia itself, the benefits of complying with the regulations are the avoidance from administrative sanctions stated on each regulations. Hence, modern retailers are liberated from the possibility of being given written sanction, or having their license suspend up to being terminated.

On the Annex Illustrative List of TRIMs Agreement, it was stated that TRIMs policies that are not in accordance with the National Treatment must be policies that require the purchase or use of certain domestic products, which are determined in terms of product, volume, or proportion of certain products. local production value. In the regulations, this is determined by the amount of the use of certain domestic products at $80 \%$ (eighty percent) to be sold at modern retails which proves that this condition has been proven. Hence, all five of charcteristics that make a Local Content Requirements policies are in accordance to TRIMs Agreement are proven.

Even though WTO provisions in GATT and TRIMs Agreement seems strict, there are exceptions provided in both agreements that makes member countries able to temporarily deviate from the provision. These exceptions are available in whether it is an exception to a GATT principle or specifically stated in TRIMs Agreement. 
Article 8a Paragraph III GATT contains an exception for the National Treatment principle. There are three conditions to exempt the principle (Hestermeyer \& Nilsen, 2014), there are: First, these rules must be in the form of laws, regulations or requirements governing the procurement of products purchased. Second, it must involves 'procurement by Government institutions'. Third, procurement must be carried out for Government purposes (not for purposes of commercial resale and not for the purpose of being used in the production of goods for commercial sale). However, the modern retail regulation in Indonesia are not applicable to this exception due to their goods procurement are not involving government institutions and their procurement is for commercial resale.

Following the first paragraph of the Article XI GATT, the second paragraph of the same article contains exceptions allowing deviations from the provisions in the first paragraph. There are three conditions where exceptions can be applied, those are: (1) Export prohibitions or restrictions that temporarily applied to prevent or relieve critical shortages of foodstuffs or other products essential to the exporting contracting party; (2) Import and export prohibitions or restrictions necessary to the application of standards or regulations for the classification, grading or marketing of commodities in international trade; and (3) Import restrictions on any agricultural or fisheries product, imported in any form, necessary to the enforcement of governmental measures which operate: (i) to restrict the quantities of the like domestic product permitted to be marketed or produced, or, if there is no substantial domestic production of the like product, of a domestic product for which the imported product can be directly substituted; or (ii) to remove a temporary surplus of the like domestic product, or, if there is no substantial domestic production of the like product, of a domestic product for which the imported product can be directly substituted, by making the surplus available to certain groups of domestic consumers free of charge or at prices below the current market level; or (iii) to restrict the quantities permitted to be produced of any animal product the production of which is directly dependent, wholly or mainly, on the imported commodity, if the domestic production of that commodity is relatively negligible. Among those exceptions stated, there is no suitable exception for this modern retail case.

Sood (2011) categorized other than that two exceptions specialized on each Articles, GATT also provides exception on Article XII regarding Protection of the Balance of Payments, an exception for countries protecting their foreign balance of payments by limiting their quotas and gradually reducing this exception when the problem has been solved Next, Article XIX regarding Safeguards Measure also gives an exception to importing countries which, because its domestic industry suffers serious losses due to the increase in imports of similar products, is not subject to this principle. Finally, Article XX and XXI regarding General Exceptions stated that in the interest of public health, national safety and security of importing countries, member countries can free themselves from the obligation to submit to GATT principles. It must first be proven on whether the implementation of Indonesia's modern retail regulation are indeed, because of situations that can allow itself to be liberated from the obligation to obey GATT provisions.

The provisions of the TRIMs Agreement also include exceptions. Article III TRIMs Agreement clearly stipulates exceptions that all exceptions in the GATT also apply to the provisions of the TRIMS Agreement, given the exceptions to safeguarding the balance of payments, promoting development objectives, and preserving national security and social health (Maskus \& Eby, s.a.). In addition, Article IV of the Agreement on TRIMs also provides exceptions for developing countries. The purpose of this article is that WTO member countries included in the category of developing countries may temporarily deviate from the provisions of TRIMs Agreement according to Article XVIII GATT.

Provisions for submitting exceptions of The TRIMs Agreement is regulated in Article V stating that WTO members on January 1, 1995 are required to notify the Council for Trade in Goods within 90 (ninety) days after the WTO Establishment Agreement enters into force, concerning TRIMs which are not in accordance with the TRIMs Agreement (UNCTAD, 2007). Indonesia as a developing country (Hanushek, 2013) should be able to utilize the extension five years from the date of entry into force of the WTO Agreement in accordance with ratification in Law No. 7 of 1994 stating the enactment of the Law starting January 1, 1995 to eliminate TRIMs that are not in accordance with the TRIMs Agreement and request extensions to extend the transition period. However, Indonesia never make a request for deviation from the TRIMs Agreement from the start, so that Indonesia's right to carry out TRIMs that deviated from the TRIMs Agreement never existed.

\section{CONCLUSION}

In conclusion, the regulation of Tingkat Komponen Dalam Negeri regarding modern retail in Regulations 53/2012, 68/2012 and 70/2013 and 56/2014 concerning the sale of domestic production of merchandise at least $80 \%$ (eighty percent) does not follow the National Treatment principle in Article III GATT and the General Elimination of Quantitative Restrictions principle in Article XI GATT. Both articles are the basic principles of the TRIMs Agreement, so this provision also violates the Agreement on TRIMs along with the characteristics that considers a trade to contain Local Content Requirements. The exceptions on either GATT or TRIMs Agreement cannot be applied in Indonesia's modern retail case as it is not adjustable to the case. 


\section{REFERENCES}

[1] Adolf, H. (2004). Perjanjian Penanaman Modal dalam Hukum Perdagangan Internasional. Jakarta: PT RajaGrafindo Persada.

[2] Adolf, H. (2006). Hukum Perdagangan Internasional. Jakarta: PT Raja Grafindo Persada.

[3] Adolf, H., \& Chandrawulan, A.-A. (1994). Masalah-Masalah Hukum dalam Perdagangan Internasional. Jakarta: Raja Grafindo Persada.

[4] Bora, B. (2002). Trade-Related Investment Measures. In B. Hoekman, A. Mattoo, \& P. English, Development, Trade, and WTO (pp. 171178). Washington DC: The World Bank.

[5] Carasco, E. F. (1983). The Foreign Investment Review Agency (FIRA) and The General Agreement of Tarriffs and Trafe (GATT): Incompatible? Georgia Journal of International and Comparative Law, 13(1), 441-463.

[6] Das, B. L. (2007). The World Trade Organisation: A Guide to the Framework for International Trade. India: Bookwell.

[7] Dattu, R. (2000). A Journey from Havana to Paris: The Fifty-Year Quest for the Elusive Multilateral Agreement on Investment. Fordham International Law Journal, 24(1), 275-316.

[8] Dewanti, E. H. (2012, September-December). Persyaratan Kandungan Lokal (Local Content Requirements) di Indonesia dan Kaitannya dengan Perjanjian Internasional dii Bidang Investasi. Yuridika, 203-216.

[9] Dirdjosisworo, S. (2004). Kaidah-Kaidah Hukum Perdagangan Internasional (Perdagangan Multilateral) Versi Organisasi Perdagangan Dunia $($ World Trade Organization $=$ WTO $)$. Bandung: CV Utomo.

[10] Dube, M. (2012). The Way Forward fot the WTO: Reforming the Decision-Making Process. -: South African Institute of International Affairs: Occasional Paper No. 118.

[11] Hanushek, E. (2013). Economic Growth in Developing Countries: The Role of Human Capital. Economics of Education Review(37), 204-212.

[12] Hestermeyer, H., \& Nilsen, L. (2014). The Legality of Local Content Measures Under WTO Law. Journal of World Trade, 48(3), 553-591.

[13] Hikmawati, D., \& Nuryakin, C. (2017, October). Keberadaan Ritel Modern dan Dampaknya terhadap Pasar Tradisional di DKI Jakarta. Jurnal Ekonomi dan Pembangunan Indonesia , 17(2), 195208.
[14] Jackson, J. H. (1969). World Trade and the Law of GATT: A Legal Analysis of the General Agreement on Tariffs and Trade. Charlottesville, Virginia: The Michie Company Law Publishers.

[15] Kalyuzhnova, Y. e. (2016). Local Content Policies in Resource-Rich Countries. London: Macmillan Publisher Ltd.

[16] Kartadjoemena, H. (1996). GATT dan WTO: Sistem, Forum, dan Lembaga Internasional di Bidang Perdagangan. Jakarta: UI Press.

[17] Kusumaatmadja, M. (1996). Investasi di Indonesia dalam Kaitannya dengan Pelaksanaan Perjanjian Hasil Putaran Uruguay. Jurnal Hukum, 3(5), 1-8.

[18] Macrory, P. F., Appleton, A. E., \& Plummer, M. G. (2005). The World Trade Organization: Legal, Economic, and Political Analysis (Vol. I). USA: Springer Science Business Media Inc.

[19] Martinus, H. (2011, October). Analisis Industri Retail Nasional. Humaniora, 2(2), 195-208.

[20] Maskus, K. E., \& Eby, D. R. (s.a.). Developing New Rules and Disciplines on Trade-Related Investment Measures. Michigan: Research Seminar in International Economics.

[21] Report of the Panel "Canada - Cerain Measures Affecting the Renewable Energy Generation Sector, Canada - Measures Realting to the Feed-In Tariff Program , WT/DS412/R; WT/DS426/R (WTO Panel December 19, 2012).

[22] Shadikhojaev, S. (2008, June). National Treatment under GATT Article III:2 and its Applicability in the Context of Korea's FTAs. Journal of International Economic Studies, 12(1), 65-111.

[23] Sood, M. (2011). Hukum Perdagangan Internasional. Jakarta: PT Raja Grafindo Persada.

[24] Syahmin, A. (2007). Hukum Dagang Internasional: Dalam Kerangka Studi Analitis. Jakarta: PT RajaGrafindo Persada.

[25] UNCTAD. (2007). Elimination of TRIMS: The Experience of Selected Developing Countries. Genewa: United Nations Publications.

[26] United Nations. (2007). Elimination of TRIMs: Experienced of Selected Developing Countries. Genewa: United Nations Publication.

[27] United Nations. (2014). Local Content Requirements and The Green Economy. Genewa: United Nation Publication.

[28] Usak. (2017, June). Penyelesaian Sengketa Impor Produk Hortikultura, Hewan, dan Produk Hewan antara New Zealand dengan Indonesia. Era Hukum, 2(1), 39-65. 
[29] Vagadia, A. (2004, June). A Stude on Agreement on TRIMS and India. Paripex-Indian Journal of Research, 3(6), 116-117.

[30] van Houtte, H. (1995). The Law of International Trade. London: Sweet Maxwell.

[31] Wolfe, R. (2009, December). The WTO Single Undertaking as Negotiating Technique and Constitutive Metaphor. Journal of International Economic Law, 12(4), 835-858.

[32] World Trade Organization. (2015). Understanding the WTO. s.l.: World Trade Organization. 